\title{
Biodiesel Production from Oils Extracted from Date Pits
}

\author{
Sulaiman Al-Zuhair ${ }^{1 *}$, Hanifa Taher ${ }^{2}$, Salama Al Dhaheri ${ }^{1}$, Shereen Wajeeh ${ }^{3}$, Mutasim Nour ${ }^{4}$, \\ Emad El-Najjar ${ }^{3}$
}

${ }^{1}$ Chemical and Petroleum Engineering Department, UAE University, Al Ain, United Arab Emirates

${ }^{2}$ Chemical and Environmental Engineering Department, Masdar Institute, Abu Dhabi, United Arab Emirates

${ }^{3}$ Mechanical Engineering Department, UAE University, Al Ain, United Arab Emirates

${ }^{4}$ School of Engineering \& Physical Sciences, Heriot-Watt University Dubai Campus, Dubai, United Arab Emirates

Email: ${ }^{\star}$ s.alzuhair@uaeu.ac.ae

How to cite this paper: Al-Zuhair, S., Taher, H., Al Dhaheri, S., Wajeeh, S., Nour, M. and El-Najjar, E. (2017) Biodiesel Production from Oils Extracted from Date Pits. Green and Sustainable Chemistry, 7, 48-56. https://doi.org/10.4236/gsc.2017.71004

Received: December 16, 2016

Accepted: February 21, 2017

Published: February 24, 2017

Copyright (C) 2017 by authors and Scientific Research Publishing Inc. This work is licensed under the Creative Commons Attribution International License (CC BY 4.0).

http://creativecommons.org/licenses/by/4.0/

(c) (i) Open Access

\begin{abstract}
Biodiesel production had received a considerable attention as a green, nontoxic and renewable alternative to petroleum diesel. To avoid using vegetable oils, which are expensive and compete with food, as feedstock, waste oils have been proposed. However, these waste materials contain a large amount of free fatty acids that complicates the production process. In this work, biodiesel production using an alternative feedstock; namely oils from date-pits, has been investigated. These oils have the same favorable features of straight oils, and at the same time are considered waste, since they are extracted from a waste material. The yield of oils extracted using $n$-hexane in a Soxhlet apparatus was compared to that of oils extracted using methanol-chloroform solvent mixture. The extracted oils were then converted to biodiesel via transesterification with methanol in presence of Novozym 435 or Eversa"Transform. The highest oils extraction yield of $11.7 \%$, per dry weight sample, was obtained using Soxhlet extraction apparatus compared to $8.9 \%$ using methanol-chloroform mixture. The highest biodiesel production yield was $30 \%$ of the oil used, achieved after 6 hours using Novozym 435 at $40^{\circ} \mathrm{C}$, 5:1 methanol to oil molar ratio and $10 \mathrm{wt} \%$ enzyme loading. By using a chemical alkaline catalyst, $\mathrm{NaOH}$, at the same conditions, the yield was $27 \%$.
\end{abstract}

\section{Keywords}

Date Pits, Soxhlet, Lipase, Biodiesel, Enzymatic Reaction

\section{Introduction}

Biodiesel, a mixture of fatty acid methyl esters (FAME), is commonly produced from oil-rich feedstocks, such as vegetable oils, animal fats, waste cooking oils 
and microalgae lipids. Commercially, the production takes place via transesterification using alkali catalysts. Although high yields have been reported, the main drawback of such process is in the soap formation when a feedstock with high free fatty acids (FFAs) content is used. Acid pre-treatment therefore become necessary prior to alkali transesterification. Lipases, on the other hand, can catalyze both FFAs esterification and triglycerides transesterification to produce high quality biodiesel [1] [2]. This process has been extensively studied using Novozym 435 , which is the immobilized form of Candida antarctica lipase B.

The selection of the proper feedstock depends on the contents of water and FFAs present in the extracted oil. Date palm trees are commonly cultivated in United Arab Emirates, and used for date production [3]. Date seeds (pits) are the main waste products from the date industry, which are currently used either as animal feed or directly burned for heating. Utilization of date pits in the production of high value products has received considerable attention. For example, they have been used to produce activated carbons for wastewater treatment [4] [5] [6] [7].

It was reported that about $10 \%$ of pits chemical composition is oil, with less than 1\% FFAs [8] [9] [10], which suggests their suitability to be used for biodiesel production. Although several studies had considered the date-pits characterization, Jamil et al. [11] was one of a few researchers who tested the production of biodiesel from oils extracted from date pits using potassium hydroxide $(\mathrm{KOH})$. In the present study oil was extracted from date pits using a single solvent, $n$-hexane, in a dynamic Soxhlet system, and the extraction yield was compared to that achieved using methanol-chloroform solvent mixture in a static extraction process. The extracted oil was used then as a feedstock for biodiesel production catalyzed by lipase, and the production yield was compared to that achieved using conventional alkaline catalyst, sodium hydroxide $(\mathrm{NaOH})$. A comparison between immobilized and free lipase has also been considered.

\section{Materials and Methods}

\subsection{Chemicals and Enzymes}

All chemicals used in this work were of analytical grade and purchased from Sigma Aldrich, US. The reference standards of FAMEs containing; $4 \%$ myristic acid, $10 \%$ palmitic acid, $6.0 \%$ stearic acid, 35\% oleic acid, $36.0 \%$ linoleic acid, $5.0 \%$ archidonic acid and $4 \%$ behenic acid were also obtained from Sigma Aldrich, US. High purity gases of helium $(\mathrm{He})$, hydrogen $\left(\mathrm{H}_{2}\right)$ and zero-air were supplied by Abu-Dhabi Oxygen Oxygen Company, UAE. Novozym 435 of 10,800 PLU.g ${ }^{-1}$ (propyl laurate units per gram) enzyme activity and $2 \%$ water content was purchased from Novozyms A/S, Denmark. Samples of Eversa Transform lipase formulation, produced by submerged fermentation of a genetically modified Aspergillus oryzae of 100,000 PLU.g ${ }^{-1}$, which is close to that of Novozym 435 , was a kind gift from the same supplier. Both enzymes were stored below $8^{\circ} \mathrm{C}$ and above $0^{\circ} \mathrm{C}$ according to the supplier's instructions. 


\subsection{Date Pits Approximate Analysis}

The proximate analysis of the date pits was performed using Thermo Gravimetric Analyzer (TGA-Q50). The sample approximate analysis provides information about the percentage of moisture, volatiles, fixed carbon and Ash present in the sample. After warming up and tarring procedures, a $12 \mathrm{mg}$ date pits sample was tested under constant nitrogen purging at $100 \mathrm{~mL} \cdot \mathrm{min}^{-1}$. A custom five steps heating cycle was used: Step 1: temperature was held constant at $25^{\circ} \mathrm{C}$ for $5 \mathrm{mi}-$ nutes, Step 2: temperature was ramped to $125^{\circ} \mathrm{C}$ in 5 minutes, Step 3: temperature was held at $125^{\circ} \mathrm{C}$ for 5 minutes, Step 4: temperature was ramped to $900^{\circ} \mathrm{C}$ in 38.75 minutes and Step 5: temperature was held at $900^{\circ} \mathrm{C}$ for 15 minutes.

\subsection{Oil Extraction}

Fruits of mature palm date, Khalas type, were obtained from local palm trees. Date pits were manually isolated from the fruits, socked and washed many times with tap water to remove adhering date flesh, followed by sun drying for two days. The samples were then grinded into small particles using a grinder (AR1043 Moulinex, China) for a short period of $15 \mathrm{~s}$, and then screened based on their particle size using sieve analysis (USA Standard Testing Sieves, W.S. Tyler Incorporated, USA) of $2.36,0.5$ and $0.35 \mathrm{~mm}$ mesh sizes.

Two solvent extraction methods were investigated to extract the oils, namely Soxhlet apparatus using $n$-hexane and methanol-chloroform solvent mixture. The weight of extracted oils was determined gravimetrically and used to calculate the extraction yield, as shown in Equation (1). All tests were performed in triplicate, and the results reported were the average values.

$$
\% Y=\frac{m_{\text {oil }}}{m_{\text {sample }}} \times 100
$$

where, $m_{\text {oil }}$ is the extract weight and $m_{\text {sample }}$ is the sample dry weight.

\section{1) Soxhlet Apparatus}

The dynamic extraction of oils was performed using $75 \mathrm{ml} n$-hexane in a Soxhlet apparatus (Lab-line instruments, Inc., Melrose Park, Illinois, USA). The ground and dried date pits $(3 \mathrm{~g})$ were placed in a porous cellulose thimble, which was initially dipped into $n$-hexane so that the solvent diffused completely into the sample. After $10 \mathrm{~min}$, the thimble was subjected to the system that contained $n$-hexane at $80^{\circ} \mathrm{C}$ for $12 \mathrm{~h}$. At the end of the extraction process, the oils dissolved in $n$-hexane were recovered using a rotary evaporator at $40^{\circ} \mathrm{C}$.

\section{2) Methanol-Chloroform}

Oils were also extracted from $1 \mathrm{~g}$ of biomass using a mixture of chloroform and methanol at $1: 1 \mathrm{v} / \mathrm{v}$, according to Bligh and Dyer [12] method. The samples were mixed with $40 \mathrm{ml}$ of mixture, and the extraction was allowed to equilibrate for $30 \mathrm{~min}$, under continuous ultra-sonication using Branson Sonifier 450 (Danbury, USA). This was followed by centrifuging the mixture at $3000 \mathrm{r} \cdot \mathrm{min}^{-1}$ for 5 min using IEC CL31 multispeed centrifuge (Thermo Scientific, USA). The upper aqueous layer was discarded and the lower chloroform layer containing the oils 
was separated from the solid biomass. The oils were then recovered from the chloroform layer using the rotary evaporator at $40^{\circ} \mathrm{C}$ and the oils is the solids biomass left at the bottom of extraction tube were extracted using the same procedure two more times.

\subsection{Fatty Acids Profile of Date-Pits Oils}

Oil profile was determined after derivatization to esters by methylation with $14 \%$ $\mathrm{BF}_{3}$-methanol mixture, according to Rule [13] protocol. $0.25 \mathrm{ml}$ of $14 \% \mathrm{BF}_{3}$ methanol mixture were added to $10 \mathrm{mg}$ of extracted oils, and the mixture was heated in a water bath for $45 \mathrm{~min}$ at $100^{\circ} \mathrm{C}$ and then cooled-down, followed by addition of $1 \mathrm{ml}$ of distilled water and $2 \mathrm{ml}$ of $n$-hexane, eddying and centrifuging at a low speed. The upper phase containing esters was collected and $n$ hexane was evaporated. Produced esters were then analyzed using Gas Chromatograph.

\subsection{Transesterification}

The production of biodiesel production was carried out using oils extracted via Soxhlet apparatus. Extracted oils $(1 \mathrm{ml})$ were transesterified with methanol at $40^{\circ} \mathrm{C}$ and 5:1 methanol to oil molar ratio. The reaction vials were placed in a temperature controlled water bath (Daihan Labtech, Korea) set at $40^{\circ} \mathrm{C}$ at 90 $\mathrm{r} \cdot \mathrm{min}^{-1}$. In the alkali based transesterification, the extracted oils were mixed with methoxide solution, prepared by dissolving $0.1 \mathrm{~g}$ (correspond to $10 \%$ catalysts) of $\mathrm{NaOH}$ in methanol. In enzymatic reactions, the $0.1 \mathrm{~g} \mathrm{NaOH}$ was replaced with $0.1 \mathrm{~g}$ of enzyme, either Novozym ${ }^{\oplus} 435$ or Eversa ${ }^{\oplus}$ Transformlipase. Due to methanol negative effect on lipase activity, the specified amount of oil and enzyme were first added to the reaction vial, followed by the methanol addition. After six hours, $n$-hexane was added to dissolve the produced biodiesel, which was then separated by centrifugation in at $3000 \mathrm{r} \cdot \mathrm{min}^{-1}$ for $5 \mathrm{~min}$.

\subsection{Analysis}

Fatty acid compositions of extracted oils via Soxhlet was determined using Varian Gas Chromatography (GC) (CP-3800, USA) equipped with flame ionization detector (FID) and CP-Sil 88 FAME capillary column $(100 \mathrm{~m} \times 0.25 \mathrm{~mm} \times 0.2$ $\mu \mathrm{m}$, Varian, USA) with auto-injector (CP 8410. Varian, USA). The column temperature was programmed from $150^{\circ} \mathrm{C}$ to $220^{\circ} \mathrm{C}$ at $4^{\circ} \mathrm{C} / \mathrm{min}$ and the injector and detector temperature were set at $260^{\circ} \mathrm{C}$.

The amount of produced FAME during transesterification reactions were also determined using the GC. The identification and quantification of the products were achieved by comparing them with FAME standards. Then the biodiesel yield \% was found using Equation (2).

$$
\% Y_{\text {FAME }}=\frac{m_{\text {FAME }}}{m_{\text {oil }}} \times 100
$$

where, $m_{\text {FAME }}$ is the total produced esters found in produced sample. 


\section{Results and Discussion}

\subsection{TGA Results}

The TGA results can be used to determine the proximate analysis of the date pits and can also be used to quantify the oils content. Figure 1 shows the percentage of weight loss as a function of temperature and its corresponding thermogravimetric derivative analysis (DTG).

The pyrolysis underwent three steps: 1) dehydration, 2) devolatilization and 3) solid decomposition. The first dehydration stage began from the room temperature to around $220^{\circ} \mathrm{C}$, where moisture was released and weight loss of around $3 \%$ was recorded. This low value is expected, as dried date pits were used. The major biomass reduction was observed in the second devolatilization stage at temperatures between $220^{\circ} \mathrm{C}$ and $500^{\circ} \mathrm{C}$, with weight loss of about $75 \%$. It is found that the devolatilization went through the two steps demonstrated by the two peaks. The first peak, at around $300^{\circ} \mathrm{C}$, is attributed to protein and carbohydrate devolatilization, and shows that their combined content was $(55 \%-3 \%$ $=52 \%)$. The second peak, at around $390^{\circ} \mathrm{C}$, is attributed to lipids, and shows that its content was $(65 \%-55 \%=10 \%)$. This result agrees with the gravitational determination of the oils in the date pits. In the third solids decomposition stage, the carbonaceous solids were degraded.

\subsection{Date-Pits Oil Extraction Yield and Profile}

For comparison, the dynamic extraction in the Soxhlet apparatus using $n$ hexane, which is commonly used as a baseline to evaluate extraction processes efficiency was compared to that of static extraction using solvents mixture, namely methanol-chloroform (1:1). Sample of different sizes were tested. It is important to note that the in the static mode, the extraction was assisted by ultra-sonication, which was not the case in Soxhlet tests. Table 1 shows the percentage of extracted oils from the different particle sizes. The performances of

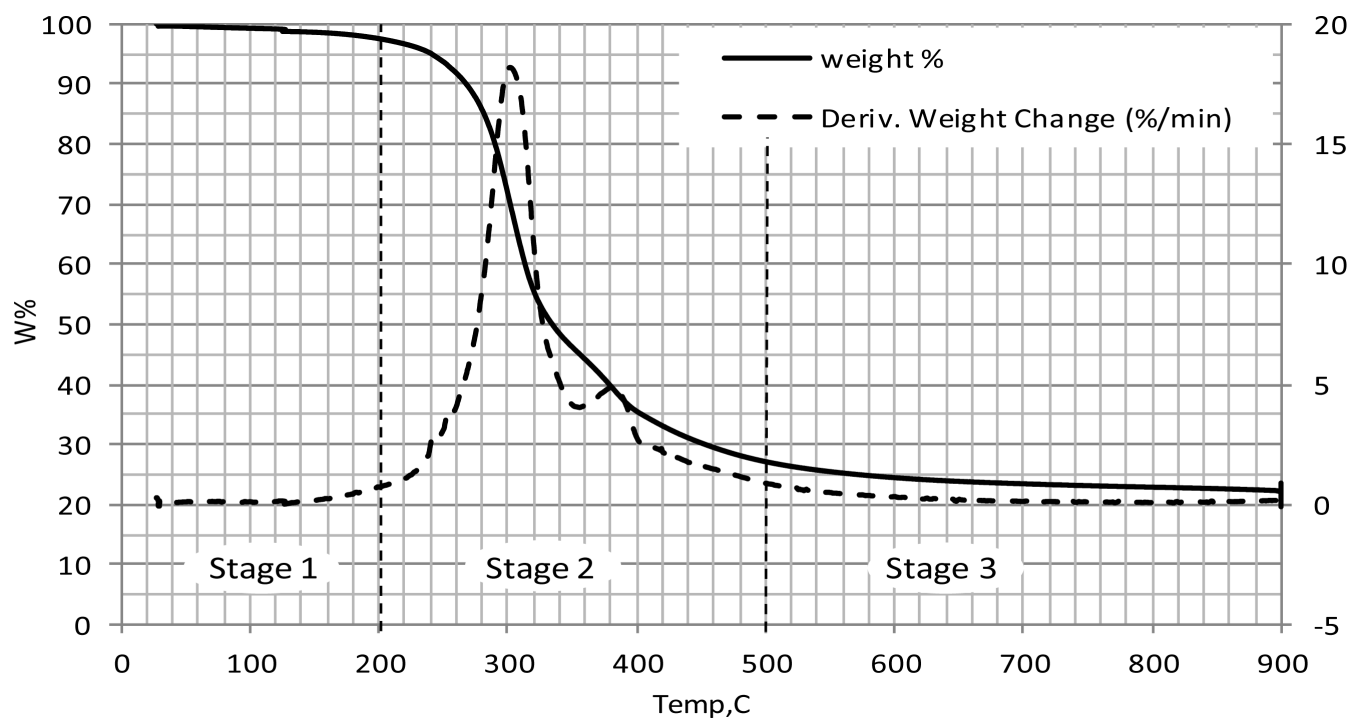

Figure 1. TGA and DTG curves of date pits. 
both methods were comparable, with Soxhlet extraction showing better performance for smaller sizes samples. When large particles were used, Soxhlet extraction was less effective than the static method. This was expected as ultrasoniccation enhanced the extraction efficiency by a caustic-induced cavitation that can disrupt the sample and facilitate solvent penetration, and therefore enhanced the contact between the solvent and the solute. The comparison revealed that dynamic extraction was $18 \%$ and $31 \%$ higher than the static mode when medium and small particle size samples were used, respectively. By decreasing samples particle sizes, the extraction yield increased dramatically for more than 3 folds, reaching $11.67 \%$ when $n$-hexane was used with small size particles, compared to the large particles. The effect was less when the static mode was tested, where only $8.9 \%$ yield of oil was obtained with small size samples (equivalent to $75 \%$ of total extractable oils using $n$-hexane). Generally, by reducing particle size, the increased specific surface area enhances oils exposure to the solvent, therefore dissolving and extracting more oils. The results found in this work are in agreement with previously reported oil contents in date pits [8] [9] [10] [11].

The composition of extracted oils was determined, and the results are shown in Table 2. As shown, extracted oils contained mainly of trans-9-elaidic and linoleic acids. These together accounts for more than $45 \%$ of the total fatty acids present in the oil. Palmitic acid is the second highest acid in accounting for around $20 \%$ followed by myristic and stearic acids. The results found in this work were in agreement with previous results on date pits [10] [14] and other potentials biodiesel feed stocks, such as microalgae lipids [15].

Table 1. Effect of samples particle size on extracted oil yield.

\begin{tabular}{ccc}
\hline Size of sample (PS) & \multicolumn{2}{c}{ Extraction yield } \\
\cline { 2 - 3 } Large $($ PS $>2.36 \mathrm{~mm})$ & Soxhlet & Methanol:Chloroform \\
\hline Medium $(2.36 \mathrm{~mm}>$ PS $>0.5 \mathrm{~mm})$ & $2.38 \%$ & $3.19 \%$ \\
Small $(0.5 \mathrm{~mm}>$ PS $>0.35 \mathrm{~mm})$ & $7.95 \%$ & $6.72 \%$ \\
\hline
\end{tabular}

Table 2. Date-pits oil composition.

\begin{tabular}{cc}
\hline Fatty Acid & Composition, w/w\% \\
\hline Unidentified & 11.3 \\
Myristic & 9.4 \\
Palmitic & 19.8 \\
Stearic & 8.6 \\
Trans-9-Elaidic & 32.6 \\
Linoleic & 14.0 \\
Linolenic & 2.9 \\
Archidic & 0.2 \\
Behenic & 1.1 \\
\hline
\end{tabular}




\subsection{Biodiesel Production}

The production of biodiesel from extracted date pits oils was tested using different catalysts; namely $\mathrm{NaOH}$, Eversa Transform and Novozym 435 . Reactions were carried out with methanol to oil molar ratio of 5:1 for six hours. Produced FAMEs were dissolved in $10 \mathrm{ml} n$-hexane before being analyzed. Comparable yields were obtained when the reaction was carried using Novozym 435 and $\mathrm{NaOH}$. As shown in Figure 2, the highest yield, reaching 30\%, was achieved in the presence of Novozym 435 . A slightly lower yield of $27 \%$ was obtained in $\mathrm{NaOH}$. By using Eversa"Transform a yield of only $11 \%$ was achieved.

Despite the comparable yields obtained using Novozym 435 and $\mathrm{NaOH}$, the profiles of the produced esters were different, as shown in Figure 2. It was found that the selectivity of $\mathrm{NaOH}$ was high toward transesterifyingtrans-9-elaidic acids compared to other acids. Whereas Novozym 435 equally transestrified most acids present in the oil sample. Similar observation was also found using the liquid Eversa Transform lipase. It is important to mention that this is the first work to test the use of this lipase in biodiesel production

\section{Conclusion}

The potential of using waste date-pits as a new source for oil to be used in biodiesel production was examined. From grinded date pits, in size ranging of 0.5 $0.35 \mathrm{~mm}$, maximum extraction yields of $11 \%$ and $7.9 \%$ were achieved using Soxhlet and methanol-chloroform solvent mixture extraction methods, respectively. The effectiveness of using lipase from different sources in producing the biodiesel was investigated, and compared to that of conventional alkaline catalyst. The highest biodiesel yield of $30 \%$ was obtained at $40^{\circ} \mathrm{C}, 5: 1$ methanol to molar ratio after $6 \mathrm{hrs}$ using Novozym 435 . The possibility of using liquid

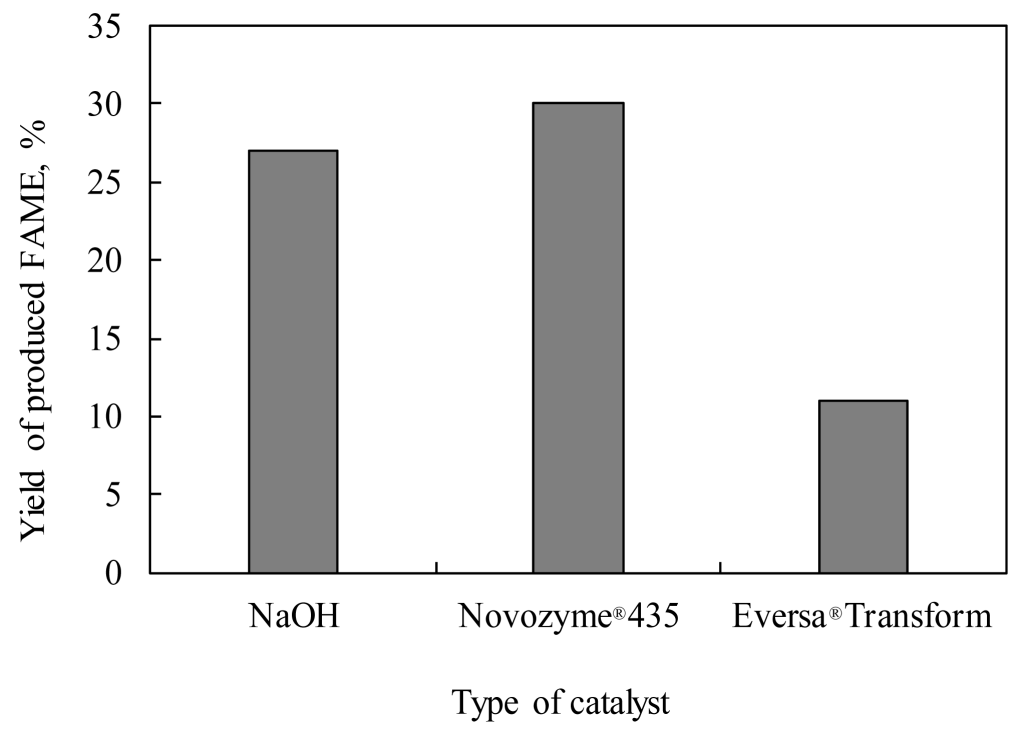

Figure 2. Biodiesel production yield after six hours from oils extracted from date pits using different enzymes. 
Eversa Transform lipase was also examined; however, a lower yield was obtained.

\section{References}

[1] Taher, H., Al-Zuhair, S., Al-Marzouqi, A.H., Haik, Y. and Farid, M.M. (2011) A Review of Enzymatic Transesterification of Microalgal Oil-Based Biodiesel Using Supercritical Technology. Enzyme Research, 2011, 25 p.

[2] Yadav, G.D. and Devi, K.M. (2004) Immobilized Lipase-Catalysed Esterification and Transesterification Reactions in Non-Aqueous Media for the Synthesis of Tetrahydrofurfuryl Butyrate: Comparison and Kinetic Modeling. Chemical Engineering Science, 59, 373-383. https://doi.org/10.1016/j.ces.2003.09.034

[3] Chisti, Y. (2007) Biodiesel from Microalgae. Biotechnology Advances, 25, 294-306. https://doi.org/10.1016/j.biotechadv.2007.02.001

[4] Ahmed, M.J. (2016) Preparation of Activated Carbons from Date (Phoenix Dactylifera L.) Palm Stones and Application for Wastewater Treatments: Review. Process Safety and Environmental Protection, 102, 168-182. https://doi.org/10.1016/j.psep.2016.03.010

[5] El-Naas, M.H., Al-Zuhair, S. and Alhaija, M.A. (2010) Reduction of Cod in Refinery Wastewater through Adsorption on Date-Pit Activated Carbon. Journal of Hazardous Materials, 173, 750-757. https://doi.org/10.1016/j.jhazmat.2009.09.002

[6] Reddy, K.S.K., Al Shoaibi, A. and Srinivasakannan, C. (2012) Activated Carbon from Date Palm Seed: Process Optimization Using Response Surface Methodology. Waste and Biomass Valorization, 3, 149-156. https://doi.org/10.1007/s12649-011-9104-4

[7] Girgis, B.S. and El-Hendawy, A.-N.A. (2002) Porosity Development in Activated Carbons Obtained from Date Pits under Chemical Activation with Phosphoric Acid. Microporous and Mesoporous Materials, 52, 105-117. https://doi.org/10.1016/S1387-1811(01)00481-4

[8] Hamada, J.S., Hashim, I.B. and Sharif, F.A. (2002) Preliminary Analysis and Potential Uses of Date Pits in Foods. Food Chemistry, 76, 135-137. https://doi.org/10.1016/S0308-8146(01)00253-9

[9] Nehdi, I., Omri, S., Khalil, M.I. and Al-Resayes, S.I. (2010) Characteristics and Chemical Composition of Date Palm (Phoenix Canariensis) Seeds and Seed Oil. Industrial Crops and Products, 32, 360-365. https://doi.org/10.1016/j.indcrop.2010.05.016

[10] Besbes, S., Blecker, C., Deroanne, C., Drira, N.-E. and Attia, H. (2004) Date Seeds: Chemical Composition and Characteristic Profiles of the Lipid Fraction. Food Chemistry, 84, 577-584. https://doi.org/10.1016/S0308-8146(03)00281-4

[11] Jamil, F., Al-Muhtaseb, A.a.H., Al-Haj, L., Al-Hinai, M.A., Hellier, P. and Rashid, U. (2016) Optimization of Oil Extraction from Waste "Date Pits" for Biodiesel Production. Energy Conversion and Management, 117, 264-272. https://doi.org/10.1016/j.enconman.2016.03.025

[12] Bligh, E.G. and Dyer, W.J. (1959) A Rapid Method of Total Lipid Extraction and Purification. Canadian Journal of Biochemistry and Physiology, 37, 911-917. https://doi.org/10.1139/059-099

[13] Rule, D.C. (1997) Direct Transesterification of Total Fatty Acids of Adipose Tissue, and of Freeze-Dried Muscle and Liver with Boron-Trifluoride in Methanol. Meat Science, 46, 23-32. https://doi.org/10.1016/S0309-1740(97)00008-9

[14] Al-Hooti, S., Sidhu, J.S. and Qabazard, H. (1997) Physicochemical Characteristics of 
Five Date Fruit Cultivars Grown in the United Arab Emirates. Plant Foods for Human Nutrition, 50, 101-113. https://doi.org/10.1007/BF02436030

[15] Taher, H., Al-Zuhair, S., Al-Marzouqi, A.H., Haik, Y. and Farid, M. (2014) Effective Extraction of Microalgae Lipids from Wet Biomass for Biodiesel Production. Biomass and Bioenergy, 66, 159-167. https://doi.org/10.1016/j.biombioe.2014.02.034

Submit or recommend next manuscript to SCIRP and we will provide best service for you:

Accepting pre-submission inquiries through Email, Facebook, LinkedIn, Twitter, etc. A wide selection of journals (inclusive of 9 subjects, more than 200 journals)

Providing 24-hour high-quality service

User-friendly online submission system

Fair and swift peer-review system

Efficient typesetting and proofreading procedure

Display of the result of downloads and visits, as well as the number of cited articles

Maximum dissemination of your research work

Submit your manuscript at: http://papersubmission.scirp.org/

Or contact gsc@scirp.org 